Bulletin of Pharmaceutical Sciences
Assiut University
$\begin{gathered}\text { Website: http://lbpsa.journals.ekb.eg/ } \\ \text { e-mail: bullpharm@aun.edu.eg }\end{gathered}$

\title{
HUMAN PLATELET LYSATE IS A GOOD ALTERNATIVE TO FETAL BOVINE SERUM IN BONE MARROW KARYOTYPING MEDIUM
}

\author{
Abdulkader Mima $^{1 *}$, Abdel Galil Ghriwati ${ }^{1}$ and Khalid Khanji ${ }^{2}$ \\ ${ }^{1}$ Department of Biotechnology Engineering, Faculty of Technology, Aleppo University, Aleppo, \\ Syria \\ ${ }^{2}$ Department of Pediatrics, Faculty of Medicine, Aleppo University, Aleppo, Syria
}

Fetal bovine serum (FBS) is frequently used as a growth factor and as a source of proteins in culture media, but it may contain pathogens.In this study, we aimed to evaluate the possibility of using human platelet lysate (HPL) as a substitute for FBSin bone marrow karyotyping medium. The study included 30 samples of bone marrow aspiration from patients attending the Aleppo University Hospital. Our results showed that the concentration of IGF-1 and $\mathrm{GH}$ in HPL was $(117 \mathrm{ng} / \mathrm{ml})$ and $(2.6 \mathrm{mIU} / \mathrm{L})$ respectively. We also determined the mitotic index (MI), and the results showed that MI values were higher when using the medium supplied with HPLcompared to medium supplied with FBS.Statistical study also showed that there were significant differences $(p=0.001)$ in MI values when comparing the two media. Our results suggest that HPLcan be used as a substitute for FBSin bone marrow karyotyping medium.

\section{INTRODUCTION}

The practice of adding serum enhancements to the culture media has always been part of in-vitro cell culture technique. These supplementations critically give the fundamental completeness required for the growth cell, metabolism, connection, generation, and differentiation of cells cultured in media ${ }^{1}$, fetal bovine serum is the serum, 'gold standard' with an overall utilization of around 800,000 liters pre-year ${ }^{2 \& 3}$. For the production of one liter of FBS are needed at least two bovine fetuses, thus amounting to around 2,000,000 embryos being used every year for this sole purpose ${ }^{2}$, despite the way that FBS is used in basically every cell culture research center, it represents the most critical raw material in the cell culture practicability. It poses different contamination risks ${ }^{4 \& 5}$, with concerns raised over the biosafety of FBS due to its ability to insert endotoxins, viral foreign substances, mycoplasma, prion proteins, and other bovine infectious agents into in-vitro cell cultures $^{6-8}$.
Moreover, FBS is an incredibly unpredictable mix, giving uncounted molecular biomolecules, for instance, growth factors, hormones, transport proteins, serum, vitamins and trace elements ${ }^{9 \& 10}$.

Many studies have indicated that serum supplements from various human sources can supplant FBS in cell culture medium and are the better decision for in-vitro societies planned for cell-based human therapies ${ }^{11}$.

Platelets are anucleate, discoid-shaped blood cells fundamental for hemostasis, which render to maintain the safety of the vasculature upon injury. The useful part of platelets has expanded in recent years to include processes for example inflammation development and advancement, irritation, natural insusceptibility, wound recuperating, angiogenesis, and malignant growth metastasis ${ }^{12}$. Because of their short life expectancy of 8-10 days in the healthy organism, around $15-40 \times 10^{9}$ platelets must be created day by day from megakaryocytes to keep up an ordinary blood tally of $150-450 \quad \mathrm{X} 10^{3} / \mathrm{mL}^{13}$, coursing inactivated platelets are biconvex discoid (lens-

Received in 19/10/2020 \& Accepted in 21/11/2020 
shaped) structures $^{14}, \quad 2-3 \mu \mathrm{m}$ in greatest diameter ${ }^{15}$.

Platelets contain three basic types of granules which are the $\alpha$-granules, dense granules and lysosomes which carry distinct cargos and vary in biogenesis, exocytosis and trafficking $^{12}$.

$\alpha$-Granules are individual to platelets and are the most copious of the platelet granules, numbering 50-80 per platelet, Proteomic studies have identified more than three hundred soluble proteins ${ }^{16}$, Contents coagulation factors (for example, factor V, factor XI, factor XIII, prothrombin, alpha 2 antiplasmin, antithrombin, plasminogen, alpha 2 macroglobulin, protein $\mathrm{S}$, plasminogen activator inhibitor-1 and tissue factor pathway inhibitor), chemokines (for example, neutrophil-activating protein-2, interleukin 8 , regulated on activation normal $\mathrm{T}$ cell expressed and secreted, monocyte chemotactic protein-1,3, macrophage inflammatory protein $1 \mathrm{a}$ and beta thromboglobulin), Adhesion molecules (fibrinogen, Pselectin, von willebrand factor, integrin aIIbB3, integrin aVB3, vitronectin, and fibronectin), immunologic molecules (for example, complement factors, factor $\mathrm{D}, \mathrm{C} 1$ inhibitor, platelet factor $\mathrm{H}, \mathrm{B} 1 \mathrm{H}$ globulin, $\mathrm{IgG}$ and thymosin B4) and regulators growth factor (For example, hepatocyte growth factor, insulin-like growth factor-1,basic fibroblast growth factor, platelet derived growth factor, vascular endothelial growth factor, brain derived neurotrophic factor, angiostatin, platelet factor 4 , connective tissue growth factor, epidermal growth factor, thrombospondin, transforming growth factor-b, angiopoietin 1, matrix metalloproteinase, endostatin, tissue inhibitor of metalloproteinases and bone morphogenetic protein) ${ }^{17}$.

The dense granules are found only in platelets and are smaller than alphagranules $^{19}$, numbering 3-8 per platelet and contain many cations (such asmagnesium, potassium and Calcium), phosphates (such aspyrophosphate and polyphosphate), bioactive amines (histamine and serotonin), nucleotides (such asADP, cAMP, ATP, UTP and GTP) and membrane proteins (such asgranulophysin CD63, GPIb, LAMP-2 and $\alpha \operatorname{IIb} \beta 3$ ).

The dense granules like lysosomes in other cell types, numbering a low 3 per platelet and contain protein enzymes (such ascollagenase, cathepsins, carboxypeptidase, elastase, and praline carboxypeptidase), carbohydrate enzymes (such asglucosidaes, galactosidase, fucosidase, glucuronidase, hexosamindase, mannosidase and arabinofuranosidase), phosphate ester cleaving (such as acid phosphatase) and membrane proteins (such asCD63, LAMP-1 and LAMP$2)^{17 \& 18}$.

The use of HPL as a promising source of growth factors for cell culture has been promoted for nearly forty years ${ }^{19}$.

The aim of this study was to determine the possibility of using human platelet lysate (HPL) as a substitute for FBS in bone marrow karyotyping medium.

\section{MATERIALS AND METHODS}

The current study was conducted in the research laboratory of the faculty of pharmacy at the university of Aleppo. The study included 30 bone marrow aspiration samples from patients attending to hematology department in Aleppo University Hospital.

\section{Preparation of human platelet lysate}

We started with four units from platelet rich plasma (PRP) units prepared by cytapheresis from Aleppo blood bank. The preparation procedure was based on repeated freeze/thaw cycles, the platelet concentrate is shock-frozen at $-30^{\circ} \mathrm{C}$ and thawed at $+37^{\circ} \mathrm{C}$ to fragment platelets three times then pooling in one bag. The pooling platelet rich plasma was fractionated to get suitable aliquots for further processing using centrifuge tubes (15 milliliters). To increase the rate of platelet fragmentation and the amount of released growth factors, a further freeze/thaw step (Freeze the small bags of portioned shockfrozen at $-30^{\circ} \mathrm{C}$ and thawed at $+37^{\circ} \mathrm{C}$ ) was repeated. Then, the tubes were centrifuged at 4,000g (30 min., $4^{\circ} \mathrm{C}$ ), and -in a laminar flow Cabinet - the supernatant plasma was collected, filtered through $(0.20 \mu \mathrm{m})$, and transferred to the final storage tubes. The platelet pellets were discarded to avoid fragments in cell culture $^{20}$. 


\section{Biochemical tests}

The concentrations of total protein, albumin, immunoglobulin, calcium, potassium, sodium and magnesium (determined by mindray BS 300), insulin-like growth factor-1 (determined by enzyme-linked immunosorbent assay, DiaMetra kit), and growth factor (determined byelecsys 2010 immunoanalyzer) were determined in human platelet lysateunits.

\section{Mitotic index}

The current study included 30 bone marrow aspiration samples. Approximately 0.5 $\mathrm{ml}$ of bone marrow suspension was cultured in a sample tubes with $10 \mathrm{ml}$ of RPMI 1460 medium supplemented with $20 \%$ human platelet lysate, and in a control tubes with 10 $\mathrm{ml}$ of RPMI 1460 medium supplemented with $20 \%$ fetal bovine serum. The tubes were incubated at $\left(37^{\circ} \mathrm{C}, 5 \% \mathrm{CO}_{2}\right)$ for $48 \mathrm{hrs}$, then $200 \mu \mathrm{l}$ of colcemid solution $(10 \mu \mathrm{g} / \mathrm{ml})$ was added and the tubes were incubated for $60 \mathrm{~min}$. After that, the tubes were centrifuged at $500 \mathrm{~g}$ for $10 \mathrm{~min}$. The supernatants were discarded and the cells were resuspended in $10 \mathrm{ml}$ of KCL solution $(0.075 \mathrm{M})$, and the nincubated for 15 min. at $37^{\circ} \mathrm{C}$. Then, the sample tubes were centrifuged at $500 \mathrm{~g}$ for $5 \mathrm{~min}$., the supernatants were discarded and the cells were fixed by adding $10 \mathrm{ml}$ offresh chilled fixation solution (1 part of acetic acid and 3 parts of ethanol) drop-by-drop. The final step was repeated until we get a precipitate of leukocytes. Chromosome spreading was done by gently dropping the cell suspension from a height of $50 \mathrm{~cm}$ on a clean slide. The slides were air-dried and stained using G-banding technique.

Mitotic index was determined using the following formula ${ }^{21}$ to assess the proliferation of cell population:

\section{Mitotic Index $(\mathrm{MI})=$}

$$
\frac{\text { Number of dividing cells }}{\text { Total number of cells }} \times 100
$$

\section{Statistical analysis}

Analysis of variance was done using independent samples T- test. All statistical tests were performed using IBM statistical Package for social sciences SPSS version 24.

\section{RESULTS AND DISCUSSION}

\section{Results \\ Biochemical tests}

The concentrations of total protein, albumin, immunoglobulin, calcium, potassium, sodium and magnesium, insulin-like growth factor-1, and growth factor in human platelet lysate units were showed in table 1.

Table 1: Concentrations of some component human platelet lysate.

\begin{tabular}{|c|c|}
\hline Items & Concentrations \\
\hline Glucose & $108 \mathrm{mg} / \mathrm{dl}$ \\
\hline Total protein & $8.1 \mathrm{~g} / \mathrm{dL}$ \\
\hline Albumin & $4.4 \mathrm{~g} / \mathrm{dL}$ \\
\hline Globulin & $3.7 \mathrm{~g} / \mathrm{dL}$ \\
\hline A/G Ratio & 1.18 \\
\hline Calcium & $7.9 \mathrm{~g} / \mathrm{dl}$ \\
\hline Potassium & $3.8 \mathrm{mEq} / \mathrm{L}$ \\
\hline Sodium & $139.9 \mathrm{mEq} / \mathrm{L}$ \\
\hline Magnesium & $2.1 \mathrm{mg} / \mathrm{dl}$ \\
\hline Phosphor & $33 \mathrm{mg} / \mathrm{dl}$ \\
\hline GH & $2.6 \mathrm{mIU} / \mathrm{L}$ \\
\hline IGF-1 & $117 \mathrm{ng} / \mathrm{ml}$ \\
\hline
\end{tabular}

\section{Mitotic index}

The results showed that MI values were higher when using the medium supplied with FBS compared to medium supplied with HPL. The minimal value of mitotic index was 3.9 and 4.1 for medium with FBS and medium with HPL respectively (Table 2 ). The maximal value of mitotic index was 7.1 and 7.4 for medium with FBS and medium with HPL (Fig. 1), respectively. Also, the results demonstrated that there were significant differences $(p=$ 0.001) in MI values when comparing the two media, which indicates that the human platelet lysate is a good alternative to fetal bovine serum in bone marrow karyotyping medium (Fig. 2).

Table 2: Statistical analyzes results.

\begin{tabular}{|c|c|c|c||}
\hline \hline MI & $\begin{array}{c}\text { Sample } \\
\text { with HPL }\end{array}$ & $\begin{array}{c}\text { Control } \\
\text { with } \\
\text { FBS }\end{array}$ & \multirow{2}{*}{ P Value } \\
\cline { 1 - 3 } Minimum & 4.1 & 3.9 & \multirow{2}{*}{0.001} \\
\hline Maximum & 7.4 & 7.1 & \\
\hline Mean & 5.00 & 4.73 & \\
\hline \hline
\end{tabular}




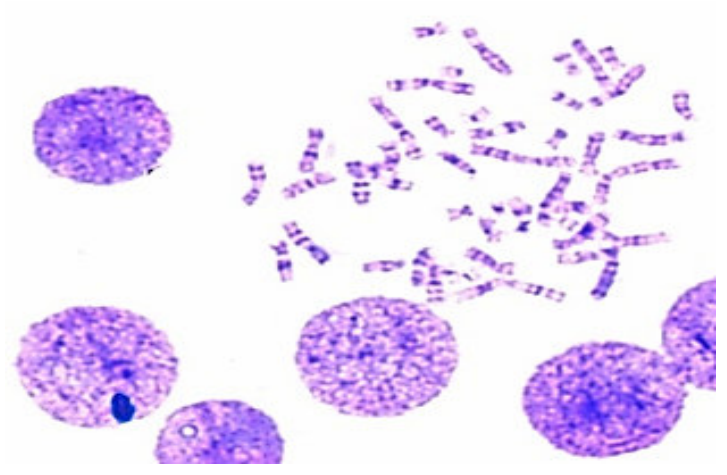

Fig. 1: Metaphase from media with human platelet serum X100.

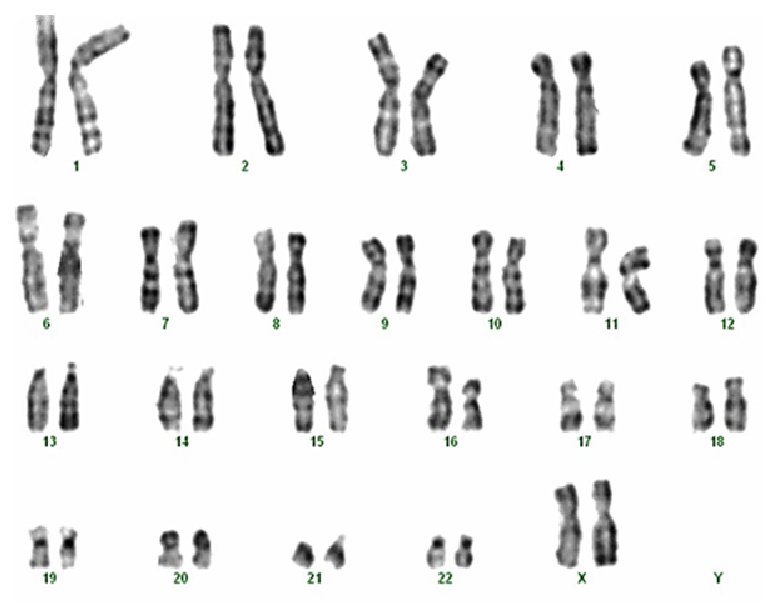

Fig. 2: Idiogram from media with human platelet serum.

\section{Discussion}

Platelets play an important role in wound restoration, Cellular growth and tissues regeneration. In the place of tissue injury, the attracted platelets not only played in make clot, but also release growth factors from their granule which are involved in cell proliferation, differentiation, and angiogenesis $^{22}$.

Up to now, FBS has been used in cell culture research, which bears the risk of xenoimmunization and transmission of known and unknown pathogens ${ }^{23}$. Over the last years, different human alternatives have been examined for their capacity to sustain proliferation and differentiation of human cells in culture ${ }^{24}$. In the past few years, it has been shown that HPL is suitable for cell culture for many cell types. For example, mesenchymal stem cells $(\mathrm{MSCs})^{25}$, fibroblasts ${ }^{26}$, keratinocytes $^{27}$, head and neck cell lines ${ }^{28}$, endothelial cells $\mathrm{s}^{29}$ and kidney cells ${ }^{30}$, peridontal ligament cells ${ }^{31}$, meniscal fibrochondrocytes ${ }^{32}$, chondrocytes $^{32 \& 33}$, myocytes ${ }^{34}$, tenocytes ${ }^{34-36}$, annulus fibrosus cells $\mathrm{s}^{37}$, and corneal epithelial cells ${ }^{38}$.

Using HPL as an effective alternative to fetal bovine serum is a great step towards a culture method that is free of animal serum. Substitutes such as autologous serum or serumfree media have not served to replace fetal bovine serum in many applications ${ }^{39}$. In previous studies, the effect of HPL and FBS on mesenchymal stromal cells expansion was compared, and the results revealed better efficiency of human platelets lysate in cell proliferation $^{40 \& 41}$.

In our study we have used three freeze/thaw cycles to induce platelet lysis shock-frozen at $-30^{\circ} \mathrm{C}$ and thawed at $37^{\circ} \mathrm{C}$ to fragment platelets. The number of cycles described in the literature varies from one to five cycles, and a determining the optimum number and precise conditions of freeze/thaw cycles is still pending ${ }^{20}$.

In the current study, we compared two different culture media, RPMI 1640 medium with 20\% FBS and RPMI 1640 medium with 20\% HPL and used mitotic index to assess the proliferation of cell population. We found that culturing bone marrow aspirator in RPMI 1640 medium with $20 \%$ HPL make a higher of mitotic index compared to RPMI 1640 medium with $20 \%$ FBS. Indicating that human platelet lysate (HPL) may serve as an efficient alternative to fetal bovine serum (FBS) in bone marrow karyotyping medium, and in tissue engineering and regenerative medicine.

\section{Acknowledgements}

This work has been supported by IBRAHIM KEBBE WAR Molecular and Cytogenetic Laboratory.

\section{REFERENCES}

1- C. Y. Fang, C. C. Wu, C. L. Fang, W. Y. Chen and C. L. Chen, "Long-term growth comparison studies of FBS and FBS alternatives in six head and neck cell lines", PLoS ONE, 12 (6), e0178960 (2017). 
2- J. van der Valk, K. Bieback, C. Buta, B. Cochrane, W. G. Dirks, J. Fu, J. J. Hickman, C. Hohensee, R. Kolar, M. Liebsch, F. Pistollato, M. Schulz, D. Thieme, T. Weber, J. Wiest, S. Winkler and G. Gstraunthaler, "Fetal bovine serum (FBS): Past - present future", ALTEX, 35 (1), 99-118 (2018).

3- H. Hemeda, B. Giebel and W. Wagner, "Evaluation of human platelet lysate versus fetal bovine serum for culture of mesenchymal stromal cells", Cytotherapy, 16 (2), 170-180 (2014).

4- Y. González Hernández and R. W. Fischer, "Serum-free culturing of mammalian cells-adaptation to and cryopreservation in fully defined media", ALTEX, 24 (2), 110-116 (2007).

5- M. Baker, "Reproducibility: Respect your cells!", Nature, 537 (7620), 433-435 (2016).

6- G. Gstraunthaler, T. Lindl and J. van der Valk, "A plea to reduce or replace fetal bovine serum in cell culture media", Cytotechnology, 65 (5), 791-793 (2013).

7- E. Fernandez-Rebollo, B. Mentrup, R. Ebert, J. Franzen, G. Abagnale, T. Sieben, A. Ostrowska, P. Hoffmann, P. F. Roux, B. Rath, M. Goodhardt, J. M. Lemaitre, O. Bischof, F. Jakob and W. Wagner, "Human platelet lysate versus fetal calf serum: These supplements do not select for different mesenchymal stromal cells", Scientific Reports, 7 (1), 5132 (2017).

8- R. Fazzina, P. Iudicone, A. Mariotti, D. Fioravanti, A. Procoli, E. Cicchetti, G. Scambia, G. Bonanno and L. Pierelli, "Culture of human cell lines by apathogen-inactivatedhuman platelet lysate", Cytotechnology, 68 (4), 11851195 (2016).

9- D. Brunner, J. Frank, H. Appl, H. Schöffl, W. Pfaller, and G. Gstraunthaler, "Serumfree cell culture: the serum-free media interactive online database", $\boldsymbol{A L T E X}, 27$ (1), 53-62 (2010).

10- X. Zheng, H. Baker, W. S. Hancock, F. Fawaz, M. McCaman, and E. Pungor, Jr, "Proteomic analysis for the assessment of different lots of fetal bovine serum as a raw material for cell culture. Part IV: Application of proteomics to the manufacture of biological drugs",
Biotechnology Progress, 22 (5), 12941300 (2006).

11- J. M. Díez, E. Bauman, R. Gajardo and J. I. Jorquera, "Culture of human mesenchymal stem cells using a candidate pharmaceutical grade xeno-free cell culture supplement derived from industrial human plasma pools", Stem Cell Research \& Therapy, 6 (1), 28 (2015).

12- X. R. Xu, D. Zhang, B. E. Oswald, N. Carrim, X. Wang, Y. Hou, Q. Zhang, C. Lavalle, T. McKeown, A. H. Marshall and H. Ni, "Platelets are versatile cells: New discoveries in hemostasis, thrombosis, immune responses, tumor metastasis and beyond", Critical Reviews in Clinical Laboratory Sciences, 53 (6), 409-430 (2016).

13- P. Gresele, N. S. Kleiman, J. A. Lopez and C. P. Page (Eds.), "Platelets in Thrombotic and Non-Thrombotic Disorders: Pathophysiology, Pharmacology and Therapeutics", "An Update", Springer, 2017, pp. 39-53.

14- N. C. Jain, "A scanning electron microscopic study of platelets of certain animal species", Thrombosis et Diathesis Haemorrhagica, 33 (3), 501-507 (1975).

15- J. M. Paulus, "Platelet size in man", Blood, 46 (3), 321-336 (1975).

16- S. W. Whiteheart, "Platelet granules: Surprise packages", Blood, 118 (5), 11901191 (2011).

17- A. Sharda and R. Flaumenhaft, "The life cycle of platelet granules", F1000Research, 7, 236 (2018).

18- A. D. Michelson, "Platelets", $3^{\text {rd }}$ Edn., Amsterdam, Academic Press, 2013, p. 1398.

19- C. T. Eastment and D. A. Sirbasku, "Human platelet lysate contains growth factor activities for established cell lines derived from various tissues of several species", In Vitro, $16 \quad$ (8), 694-705 (1980).

20- T. Burnouf, D. Strunk, M. B. Koh and K. Schallmoser, "Human platelet lysate: Replacing fetal bovine serum as a gold standard for human cell propagation?", Biomaterials, 76, 371-387 (2016).

21- S. R. Bammidi, S. S. Volluri, N. S. Satya and M. Vangalapati, "Cytotoxic and genotoxic effects of bacopamonnieri in 
the cultured human peripheral blood lymphocytes", BioSciences Regular Paper, 6 (9), 258-263 (2012).

22- A. T. Nurden, Platelets, inflammation and tissue regeneration", Thromb. Haemost., 105 Suppl 1, 13-33 (2011).

23- G. A. Tonti and F. Mannello, "From bone marrow to therapeutic applications: different behaviour and genetic/epigenetic stability during mesenchymal stem cell expansion in autologous and foetal bovine sera?", The International Journal of Developmental Biology, 52 (8), 1023 1032 (2008).

24- N. Stute, K. Holtz, M. Bubenheim, C. Lange, F. Blake and A. R. Zander, "Autologous serum for isolation and expansion of human mesenchymal stem cells for clinical use", Experimental Hematology, 32 (12), 1212-1225 (2004).

25- K. Schallmoser and D. Strunk, "Preparation of pooled human platelet lysate (pHPL) as an efficient supplement for animal serum-free human stem cell cultures", Journal of Visualized Experiments, 32, 1523 (2009).

26- V. Mirabet, P. Solves, M. D. Miñana, A. Encabo, F. Carbonell-Uberos, A. Blanquer and R. Roig, "Human platelet lysate enhances the proliferative activity of cultured human fibroblast-like cells from different tissues", Cell and Tissue Banking, 9 (1), 1-10 (2008).

27- M. C. Barsotti, P. Losi, E. Briganti, E. Sanguinetti, A. Magera, T. Al Kayal, R. Feriani, R. Di Stefano and G. Soldani, "Effect of platelet lysate on human cells involved in different phases of wound healing", PLoS ONE, 8 (12), e84753 (2013).

28- C. Y. Fang, C. C. Wu, C. L. Fang, W. Y. Chen and C. L. Chen, "Long-term growth comparison studies of FBS and FBS alternatives in six head and neck cell lines", PLoS ONE, 12 (6), e0178960 (2017).

29- T. J. Wang, M. S. Chen, M. L. Chou, H. C. Lin, J. Seghatchian and T. Burnouf, "Comparison of three human platelet lysates used as supplements for in-vitro expansion of corneal endothelium cells", Transfusion and Apheresis Science, 56 (5), 769-773 (2017).
30- K. Witzeneder, A. Lindenmair, C. Gabriel, K. Höller, D. Theiß, H. Redl, and S. Hennerbichler, "Human-derived alternatives to fetal bovine serum in cell culture", Transfusion Medicine and Hemotherapy: Offizielles Organ der Deutschen Gesellschaft fur Transfusions medizin und Immunhamatologie, 40 (6), 417-423.

31- T. Burnouf, C. Y. Lee, C. W. Luo, Y. P. Kuo, M. L. Chou, Y. W. Wu, et al., "Human blood-derived fibrin releasates: composition and use for the culture of cell lines and human primary cells", Biologicals, 40, 21-30 (2012).

32- V. K. Gonzales, E. L. de Mulder, T. de Boer, G. Hannink, T. G. van Tienen, W. L. van Heerde, and P. Buma, "Platelet-rich plasma can replace fetal bovine serum in human meniscus cell cultures", Tissue Eng. Part C. Methods, 19, 892-899 (2013).

33- C. Kaps, A. Loch, A. Haisch, H. Smolian, G. R. Burmester, T. Häupl and M. Sittinger, "Human platelet supernatant promotes proliferation but not differentiation of articular chondrocytes", Medical \& Biological Engineering \& Computing, 40 (4), 485-490 (2002).

34- F. Hildner, M. J. Eder, K. Hofer, J. Aberl, H. Redl, M. van Griensven, C. Gabriel and A. Peterbauer-Scherb, "Human platelet lysate successfully promotes proliferation and subsequent chondrogenic differentiation of adiposederived stem cells: A comparison with articular chondrocytes", Journal of Tissue Engineering and Regenerative Medicine, 9 (7), 808-818 (2015).

35- A. D. Mazzocca, M. B. McCarthy, D. M. Chowaniec, E. M. Dugdale, D. Hansen, M. P. Cote, J. P. Bradley, A. A. Romeo, R. A. Arciero and K. Beitzel, "The positive effects of different platelet-rich plasma methods on human muscle, bone, and tendon cells", The American Journal of Sports Medicine, 40 (8), 1742-1749 (2012).

36- M. de Mos, A. E. van der Windt, H. Jahr, H. T. van Schie, H. Weinans, J. A. Verhaar and G. J. van Osch, "Can plateletrich plasma enhance tendon repair? A cell culture study", The American Journal of 
Sports Medicine, 36 (6), 1171-1178 (2008).

37- X. Wang, Y. Qiu, J. Triffitt, A. Carr, Z. $\mathrm{Xia}$ and A. Sabokbar, "Proliferation and differentiation of human tenocytes in response to platelet rich plasma: an invitro and in-vivo study", Journal of Orthopaedic Research, 30 (6), 982-990 (2012).

38- T. N. Pirvu, J. E. Schroeder, M. Peroglio, S. Verrier, L. Kaplan, R. G. Richards, M. Alini and S. Grad, "Platelet-rich plasma induces annulus fibrosus cell proliferation and matrix production", European Spine Journal, 23 (4), 745-753 (2014).

39- K. Bieback, A. Hecker, A. Kocaomer, H. Lannert, K. Schallmoser, D. Strunk and H. Kluter, "Human alternatives to fetal bovine serum for the expansion of mesenchymal stromal cells from bone marrow", Stem Cells, 27 (9), 2331-2341 (2009).

40- K. Schallmoser, C. Bartmann, E. Rohde, A. Reinisch, K. Kashofer, E. Stadelmeyer, C. Drexler, G. Lanzer, W. Linkesch and D. Strunk, "Human platelet lysate can replace fetal bovine serum for clinicalscale expansion of functional mesenchymal stromal cells", Transfusion, 47 (8), 1436-1446 (2007).

41- A. Reinisch, C. Bartmann, E. Rohde, K. Schallmoser, V. Bjelic-Radisic, G. Lanzer, W. Linkesch and D. Strunk, "Humanized system to propagate cord blood-derived multipotent mesenchymal stromal cells for clinical application", Regenerative Medicine, 2 (4), 371-382 (2007). 


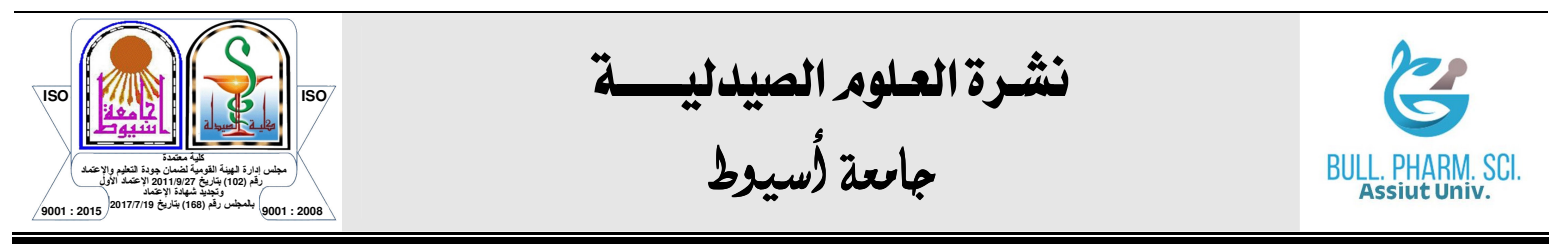

$$
\begin{aligned}
& \text { حُلكلة الصفيحات البشريَّة كبديل جيد عن المصل الجنيني البقري في أوساط الزرع الزئل }
\end{aligned}
$$

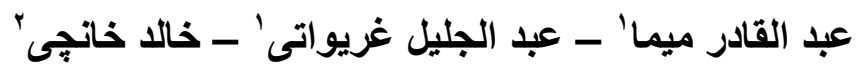

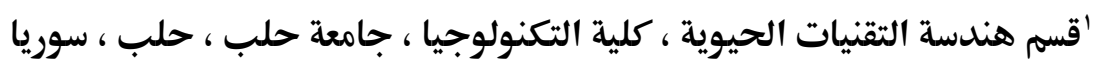

$$
\begin{aligned}
& \text { 'قسم الاطفال ، كلية الطب ، جامعة حلب ، حلب ، سوريا }
\end{aligned}
$$

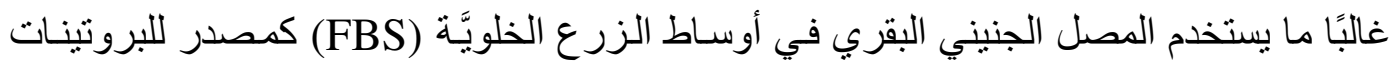

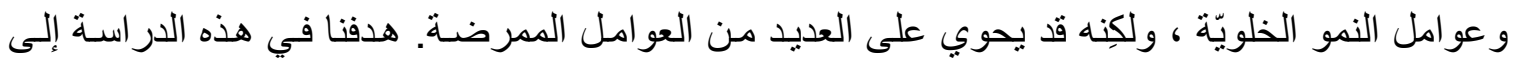

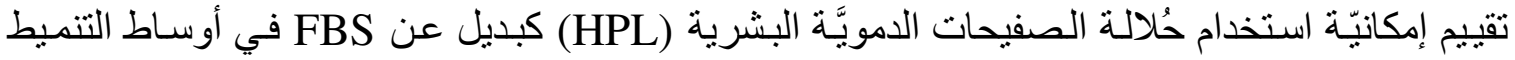

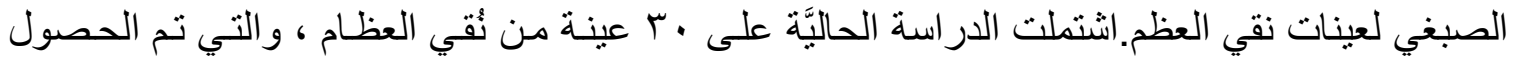

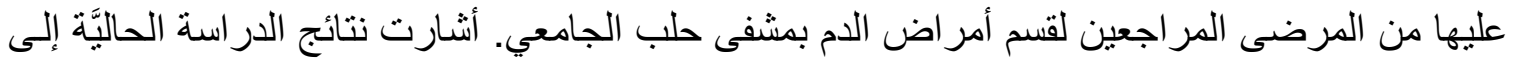

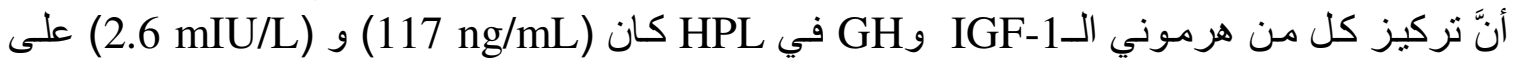

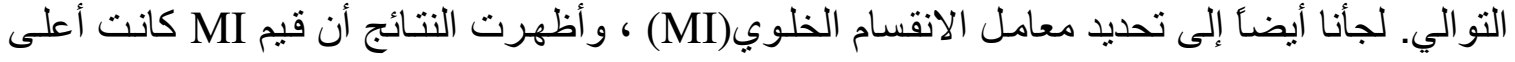

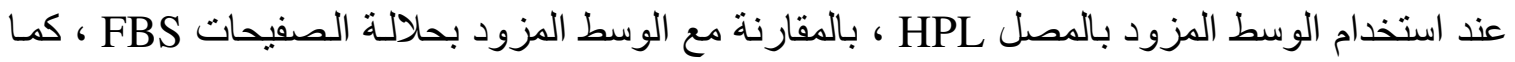

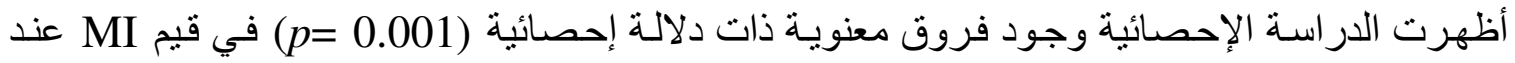

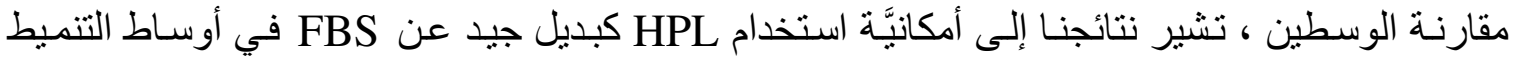
النووي لعينات نقي العظم. 